\title{
ANALISA JENIS MANGROVE MENGGUNAKAN CITRA UAV DENGAN KLASIFIKASI OBIA
}

\section{MANGROVE TYPES ANALYSIS USING UAV IMAGE WITH OBIA CLASSIFICATION}

\author{
Oleh \\ Woody A. Timisela ${ }^{1^{*}}$, Gun Mardiatmoko ${ }^{2-}$, Ferad Puturuhu $^{3}$ \\ ${ }^{1}$ Mahasiswa Program Studi Magister Manajemen Hutan Universitas Pattimura,, Ambon 97123 \\ ${ }^{2,3}$ Dosen Program Studi Magister Manajemen Hutan Universitas Pattimura, Ambon 97123 \\ E-mail : woody.timisela@gmail.com \\ \begin{tabular}{l|l} 
Diterima : 10 Maret 2020 & Disetujui :14 April 2020
\end{tabular}
}

\begin{abstract}
Abstrak
Sulitnya inventarisasi yang dilakukan di areal hutan mangrove disebabkan karena luasnya lahan hutan mangrove dengan tingkat kerapatan yang tinggi, sehingga harus menggunakan Citra Satelit Resolusi Tinggi (CSRT) yang membutuhkan biaya tinggi. Pendekatan dalam pengolahan citra resolusi sangat tinggi adalah pendekatan berbasis objek (OBIA). Perkembangan teknologi UAV menggunakan kamera yang terpasang pada UAV telah banyak digunakan dalam inventarisasi hutan yang memiliki manfaat, biaya rendah dan fleksibilitas tinggi. Oleh karena itu penelitian ini bertujuan menganalisis jenis mangrove menggunakan citra UAV dengan klasifikasi OBIA dan melakukan perhitungan model tinggi tajuk pohon pada hutan mangrove. Hasil penelitian menunjukkan bahwa uji akurasi menggunakan conffusion matriks dengan Producer accuracy untuk BG $78 \%$, CT 97 \%, RS 96,63\%, RA 91,04\%; sedangkan user accuracy untuk BG 88,89\%, CT 97,73\%, RS 97,73\% dan RA $85 \%$ dengan demikian overal accuracy $92,98 \%$.
\end{abstract}

Kata Kunci : UAV, OBIA, Citra resolusi tinggi, Jenis Mangrove.

\begin{abstract}
The difficulty of the inventory carried out in the mangrove forest area is due to the vast expanse of mangrove forests with a high-density level, so it must use High-Resolution Satellite Imagery (CSRT) which requires high costs. The approach to processing very high-resolution images is the object-based approach (OBIA). UAV technology development using cameras mounted on UAVs has been widely used in forest inventories that have benefits, low costs, and high flexibility. Therefore, this study aims to analyze the types of mangroves using UAV images with OBIA classification and calculate the tree canopy height model in mangrove forests. The results showed that the accuracy-test used a confusion matrix with Producer accuracy for BG 78\%, CT 97\%, RS 96.63\%, RA 91.04\%. In comparison, the user accuracy for BG is $88.89 \%$, CT $97.73 \%$, RS $97.73 \%$, and RA $85 \%$. Thus the overall efficiency is $92.98 \%$.
\end{abstract}

Keywords: UAV, OBIA, High-Resolution Satelite Imagery, Mangrove type.

\section{PENDAHULUAN}

Hutan Mangrove adalah hutan yang didominasi oleh vegetasi kayu yang tumbuh di daerah tropis lebih dari 100 negara dan teritori di seluruh dunia (Giri dkk. 2011). Hutan mangrove terletak di permukaan antara darat dan laut, yang menyediakan puluhan jasa ekosistem mulai secara lokal hingga secara global, termasuk stabilisasi garis pantai, perlindungan habitat dari badai (Warfield 2019). Ekosistem mangrove di Indonesia mempunyai keanekaragaman hayati tertinggi di dunia dengan jumlah species 89 jenis yang terdiri dari 35 species pohon, 5 jenis terna, 9 jenis perdu, 9 jenis liana, 29 jenis epifit dan 2 jenis parasit (Soemadihardjo et al., 1993 dalam Kusmana, 2003). Jenis-jenis pohon mangrove yang umum dijumpai di wilayah pesisir Indonesia adalah bakau (Rhizopora spp.), api-api (Avicennia spp.), pedada (Sonneratia spp.), tancang (Bruguiera spp.), nyirih (Xylocarpus spp.), tengar (Ceriops spp.) dan buta-buta 
(Excoceria spp.). Spesies pohon tersebut berasosiasi dengan ribuan spesies mamalia, burung, ikan dan invertebrata (IUCN, 1993).

Mangrove di Indonesia memiliki tingkat keanekaragaman hayati tertinggi di dunia dengan jumlah jenis adalah 89 jenis terbagi atas 35 jenis pohon, 5 jenis terna, 9 jenis perdu, 9 jenis liana, 29 jenis epifit dan dua jenis parasit (Soemadihardjo dkk., 1993 dalam Kusmana, 2003). Jenis-jenis Mangrove ini umum ditemui di pesisir Indonesia adalah Rhizopora spp. Avicennia spp, Sonneratia spp, Bruguiera spp, Xylocarpus spp, Ceriops spp dan Excoceria spp.

Kawasan Hutan Mangrove Teluk Pelita Jaya Kabupaten Seram Bagian Barat merupakan salah satu kawasan hutan mangrove besar yang ada di wilayah Kabupaten Seram Bagian Barat. Potensi flora maupun fauna yang terdapat di areal ini cukup besar salah satunya adalah hutan mangrove. Mangrove menyimpan potensi dan peluang untuk dikembangkan, namun masih jarang yang tertarik dengannya. Selain karena lokasi yang menantang, mangrove masih dianggap sebagai wasteland (lahan sampah). Mengumpulkan informasi dan data terkait vegetasi Mangrove dengan cara inventarisasi secara terestris tentunya akan membutuhkan waktu, biaya dan tenaga yang sangat besar, dikarenakan lokasinya yang berbeda dengan hutan lahan kering. Salah satu teknologi yang bisa dimanfaatkan untuk memperoleh informasi vegetasi Mangrove adalah penggunaan teknologi penginderaan jauh.

Perkembangan penginderaan jauh dalam mendukung pengelolaan sumberdaya alam memberikan peluang serta tantangan. Salah satu tantangan yang dihadapi adalah ketika semakin tinggi suatu resolusi spasial citra satelit maka dibutuhkan pendekatan yang lebih kompleks. UAV merupakan salah satu wahana yang mampu menghasilkan citra dengan resolusi sangat tinggi. Salah satu permasalahan yang dihadapi pada citra resolusi sangat tinggi adalah bagaimana pengolahan citranya. Untuk menghasilkan informasi dan data yang baik dari citra resolusi sangat tinggi tentunya diperlukan pendekatan yang berbeda dengan citra resolusi menengah dan rendah.

Pendekatan yang biasa digunakan dalam pengolahan citra resolusi sangat tinggi adalah pendekatan berbasis objek (OBIA). Perkembangan baru-baru ini teknologi UAV menggunakan kamera yang terpasang pada UAV telah banyak digunakan dalam inventarisasi hutan skala kecil yang memiliki manfaat, biaya rendah dan fleksibilitas tinggi (Zahawi, 2015). Citra dengan resolusi sangat tinggi yang berasal dari sistem UAV memiliki potensi untuk mengidentifikasi spesies Mangrove (Cao2018). Selain itu, pendekatan berbasis objek yang dikombinasikan dengan citra beresolusi tinggi sering diterapkan untuk memetakan spesies Mangrove dalam beberapa tahun terakhir (Pham, 2019). Sebagai contoh, Wang et al. (2018) menunjukkan bahwa metode berbasis objek memiliki tingkat akurasi yang lebih tinggi dibandingkan Metode berbasis Pixel untuk pemrosesan spesies mangrove yang menggunakan citra $0,5 \mathrm{~m}$ Pléiades-1. Selain itu, pencitraan fotogrammetri didukung oleh teknik struktur gerakan (SfM) dan pencocokan yang tepat karena menjadi sangat menarik untuk mengumpulkan objek informasi tiga dimensi (3D) (Westoby, 2012).

Sulitnya inventarisasi yang dilakukan di areal hutan mangrove disebabkan karena luasnya lahan hutan mangrove dengan tingkat kerapatan yang tinggi, dan dalam melakukan identifikasi harus menggunakan Citra Satelit Resolusi Tinggi (CSRT) yang untuk memperolehannya membutuhkan biaya tinggi. Berdasarkan uraian tersebut, maka penelitian ini melakukan analisis pemetaan jenis mangrove dengan menggunakan citra UAV dengan klasifikasi penerapan metode OBIA dan melakukan perhitungan Model Tinggi Tajuk Pohon pada hutan mangrove.

\section{METODE PENELITIAN}

\section{Lokasi dan Waktu Penelitian}

Penelitian dilakukan di Tanjung 
Lalansoi Pulau Osi yang secara administrasi terletak di Dusun Pelita Jaya Desa Eti Kecamatan Seram Barat. Luas lokasi penelitian sesuai hasil deliniasi yang dilakukan adalah 40 Ha.. Penelitian berlangsung dari bulan September sampai dengan Nopember 2019, khususnya di area yang terliput oleh rekaman Drone/ UAV (Unmanned Aerial Vehicle). Hak cipta dari citra UAV yang digunakan dalam penelitian merupakan hasil perekaman yang dilakukan oleh peneliti dan analisa data dari bulan Nopember 2019 sampai dengan Januari 2020.

\section{Alat dan Bahan}

Peralatan yang digunakan untuk pengambilan data di lapangan dan peralatan untuk akuisisi citra UAV beserta aplikasinya disajikan Tabel 1 dan Tabel 2. 
Tabel 1. Peralatan Penelitian

\begin{tabular}{|c|c|c|c|}
\hline No & Nama Alat & Jumlah & Fungsi \\
\hline 1 & $\begin{array}{l}\text { UAV quad-copter DJI } \\
\text { Phantom } 4 \text { Profesional }\end{array}$ & 1 set & $\begin{array}{l}\text { Drone yang yang telah } \\
\text { dilengkapi kamera terbang } \\
\text { berdasarkan rute } \\
\text { penerbangan yang } \\
\text { direncanakan }\end{array}$ \\
\hline 2 & $\begin{array}{l}\text { Receiver GPS Geodetic } \\
\text { Trimble dual frequensi }\end{array}$ & $1 \mathrm{Set}$ & $\begin{array}{l}\text { Mengukur Koordinat Titik } \\
\text { GPS secara teliti }\end{array}$ \\
\hline 3 & Handle GPS & 1 Unit & $\begin{array}{l}\text { Mengukur posisi horizontal } \\
\text { titik-titik dilapangan }\end{array}$ \\
\hline 4 & Premark & 10 buah & $\begin{array}{l}\text { Sebagai tanda pengukuran } \\
\text { titik koordinat yang nantinya } \\
\text { dapat di koreksi pada citra } \\
\text { foto udara }\end{array}$ \\
\hline 5 & Haga & 1 buah & $\begin{array}{l}\text { Untuk mengukur tinggi } \\
\text { pohon }\end{array}$ \\
\hline 6 & Phi Band & 1 buah & $\begin{array}{l}\text { Untuk mengukur diameter } \\
\text { pohon }\end{array}$ \\
\hline 7. & $\begin{array}{l}\text { Laptop Windows } 8.16 \mathrm{~b} \\
\text { bit, procecor : intel Core } \\
15-4210 \text { up to } 2.40 \\
\text { GHz, Memory } 8 \mathrm{~Gb} \\
\text { RAM }\end{array}$ & $1 \mathrm{Set}$ & $\begin{array}{l}\text { Perangkat Komputer akan } \\
\text { digunakan untuk proses } \\
\text { pengolahandata foto udara } \\
\text { yang nantinya akan } \\
\text { membentuk peta orthomosaic }\end{array}$ \\
\hline 8. & $\begin{array}{l}\text { Ipad Air dan Android } \\
\text { Samsung J } 7 \text { Pro }\end{array}$ & 2 Unit & $\begin{array}{l}\text { Sebagai perangkat } \\
\text { pengaturan flight plan dan } \\
\text { pemantauan terbang wahana }\end{array}$ \\
\hline 9 & $\begin{array}{l}\text { Perangkat Lunak DJI } \\
\text { Go IoS application dan } \\
\text { Drone Depoy }\end{array}$ & 2 unit & $\begin{array}{l}\text { Perangkat lunak untuk design } \\
\text { dan monitoring penerbangan } \\
\text { bertujuan menganalisa } \\
\text { rute,besar overlap, interval } \\
\text { pemotrtan, jumlah foto }\end{array}$ \\
\hline 10 & $\begin{array}{l}\text { Perangkat Luna GIS, } \\
\text { Arc Gis } 10.5\end{array}$ & 1 Unit & $\begin{array}{l}\text { Mengolah dan menganalisa } \\
\text { data spasial }\end{array}$ \\
\hline 11 & $\begin{array}{l}\text { Perangkat Lunak } \\
\text { Agisoft Metashape } \\
\text { Profesional Edition } \\
\text { vertion 1.5.2 Build } 7836 \\
\text { (64 bit) }\end{array}$ & 1 Unit & $\begin{array}{l}\text { Perangkat lunak pengolahan } \\
\text { foto drone, mengoreksi foto } \\
\text { hasil pemotretan dan } \\
\text { menghasilkan foto } \\
\text { orthomosaic. }\end{array}$ \\
\hline 12 & PCI Geomatica 2014 & 1 unit & $\begin{array}{l}\text { Perangkat Lunak untuk } \\
\text { pengolahan Data DTM dari } \\
\text { Data DSM }\end{array}$ \\
\hline 13 & Camera Digital & 1 Unit & $\begin{array}{l}\text { Dokumentasi kegiatan } \\
\text { Survey Lapangan }\end{array}$ \\
\hline
\end{tabular}

Gambar 1. Drone Phantom 4 Profesional

\section{Pra Pengolahan Citra}

Pra pengolahan data penginderaan jauh merupakan tahapan pengolahan data inderaja sebelum dilakukan interpretasi dan deliniasi untuk menghasilkan data sebaran mangrove. Tahap Pra Pengolahan Citra ini yaitu koreksi geometrik. 
Koreksi geometri Citra penginderaan jauh UAV adalah langkah penting dalam pretreatment citra penginderaan jauh.

\section{Pengolahan Citra Berbasis Ojek (OBIA).}

Klasifikasi adalah proses identifikasi piksel citra dengan sifat-sifat yang sama, mengorganisir ke dalam kelompok kemudian menentukan penamaan kelompok tersebut dan tahap akhir dari klasifikasi adalah peta yang memuat informasi tertentu (Green dkk. 2000). Menurut Danoedoro (2012) bahwa klasifikasi citra merupakan proses mengelompokkan piksel ke dalam kelas-kelas tertentu berdasarkan nilai kecerahan piksel (brightness value/ BV/ digital number) pada citra. Saat ini, penerapan klasifikasi citra terdapat dua pendekatan yaitu klasifikasi berbasis piksel (pixel based) dan klasifikasi berbasis objek (object based/OBIA).

Klasifikasi citra yang digunakan untuk memetakan komposisi mangrove yaitu menggunakan klasifikasi citra berbasis objek/OBIA. Metode OBIA merupakan metode klasifikasi yang dikembangkan dengan proses segmentasi dan analisis objek atau proses klasifikasi citra berdasarkan karakteristik spasial, spektral dan skala temporalnya, sehingga menghasilkan objek citra atau segmen-segmen yang selanjutnya digunakan untuk klasifikasi (Wang dkk. 2004; Blaschke 2010).

\section{Segmentasi}

Segmentasi citra adalah langkah pertama dari analisis gambar berbasis objek dan digunakan untuk menghasilkan gambar objek yang lebih homogen di antaranya sendiri daripada dengan daerah terdekat (Baatz (2017). Cheng (2014) menyatakan bahwa Ketepatan segmentasi gambar secara signifikan mempengaruhi akurasi klasifikasi berbasis objek. Benz (2004) Segmentasi Yang paling banyak digunakan adalah multi-resolusi, teknik penggabungan wilayah bottom-up, digunakan untuk menghasilkan objek gambar. Pada penelitian ini algoritma segmentasi yang digunakan yaitu algoritma multiresolution segmentation (MRS). Algoritma ini dimulai dengan piksel tunggal dan menggabungkan segmen tetangga (neighboring segments) hingga ambang batas (threshold) heterogenitas tercapai. Pada proses segmentasi dengan algoritma MRS terdapat tiga perameter penting yaitu shape (bentuk), compactness (kekompakan) dan scale (skala/ukuran) (Mastu, 2018). Shape berfungsi mengatur homogenitas spektral dan bentuk objek yang berkaitan dengan nilai digital yang dipengaruhi oleh warna. Compactness berperan dalam menyeimbangkan atau mengoptimalkan kekompakan dan kehalusan objek dalam menentukan objek antara batas yang halus dan tepi yang kompak. Scale berfungsi mengatur ukuran objek yang dapat disesuaikan dengan kebutuhan pengguna berdasarkan tingkat kedetailan. Nilai yang digunakan pada parameter shape dan compactness berkisar antara 0-1, sedangkan nilai scale merupakan suatu abstraksi dalam menentukan nilai maksimum heterogenitas untuk membangkitkan suatu objek. Oleh karena itu tidak ada ketentuan baku mengenai standar nilai parameter dalam klasifikasi berbasis objek (Benfield dkk. 2007; Phinn dkk. 2011; Trimble 2014). Semua prosedur pemrosesan gambar berbasis objek klasifikasi dilakukan menggunakan perangkat lunak eCognition Developer 9.0 (Trimble Germany GmbH, Munich, Jerman).

\section{Klasifikasi Spesies Mangrove}

Dalam Penelitian ini skema klasifikasi spesies mangrove menggunakan SVM (Skema Support Vector Macine) pengklasifikasi pembelajaran mesin berdasarkan pada dataset yang berbeda. Model klasifikasi ini semuanya dieksekusi secara computerisasi.

SVM adalah metode pembelajaran inti berbasis mesin yang terkenal, dan telah terbukti menjadi salah satu pengklasifikasi yang paling banyak digunakan dan efisien (Feret, 2012- Tan, 2017). SVM bertujuan untuk menemukan cara klasifikasi yang optimal untuk memisahkan hyperplane untuk mengasumsikan bahwa semua grup dapat dipisahkan, untuk memaksimalkan interval antara bidang didukungan dengan data setiap jenis. Hal ini memiliki kemampuan yang kuat untuk pemrosesan data nonlinier pada 
dimensi tinggi, yang dapat menghindari "bencana dimensionalitas" yang disebabkan oleh ruang sampel dimensi tinggi dan dapat diterapkan untuk pembelajaran sampel kecil. Paket LIB SVM dikembangkan oleh Chang dan Lin (2011) telah banyak digunakan untuk mengimplementasikan model klasifikasi SVM. Mempertimbangkan hyperplane nonlinear, Fungsi Dasar Radial (RBF) inti yang dipilih dan dua parameter, biaya kendala $(C)$ dan sigma $(\sigma)$, ditentukan oleh strategi pencarian grid.

\section{Survei Lapangan}

Penerapan stratifikasi awal untuk pendugaan cadangan karbon menggunakan data penginderaan jauh dapat meningkatkan keakurasian dan efektifitas biaya (GOFCGOLD, 2009). Stratified sampling juga disarankan dalam IPCC guidelines (2006). Metode stratified random sampling dan stratified systematic sampling karenanya sangat disarankan untuk digunakan di dalam pengukuran jumlah karbon di hutan tropis Indonesia yang memiliki variasi kandungan karbon yang sangat tinggi.

Metode pengambilan sampling yang digunakan dalam Identifikasi Jenis mangrove dan Estimasi Ketersediaan Biomasa adalah Metoda stratified systematik sampling, dimana sampling yang diambil pada Plot Sampling yang dibuat dengan luas areal ukuran $20 \times 20 \mathrm{~m}$ berbentuk bujur sangkar. Luas areal penelitian adalah $40 \mathrm{Ha}$ dengan intensitas sampling $1 \%$. Jarak antar plot sampling adalah $180 \mathrm{~m}$ dengan total Plot sampling yang dibuat adalah sebanyak 11 plot sampling dengan luasan $400 \mathrm{~m}^{2}$ per plot. Pengambilan sampel untuk jenis mangrove dilakukan secara menyeluruh pada setiap plot sampel degan melakukan pengukuran tinggi dan diameter dari setiap jenis mangrove yang ditemukan.

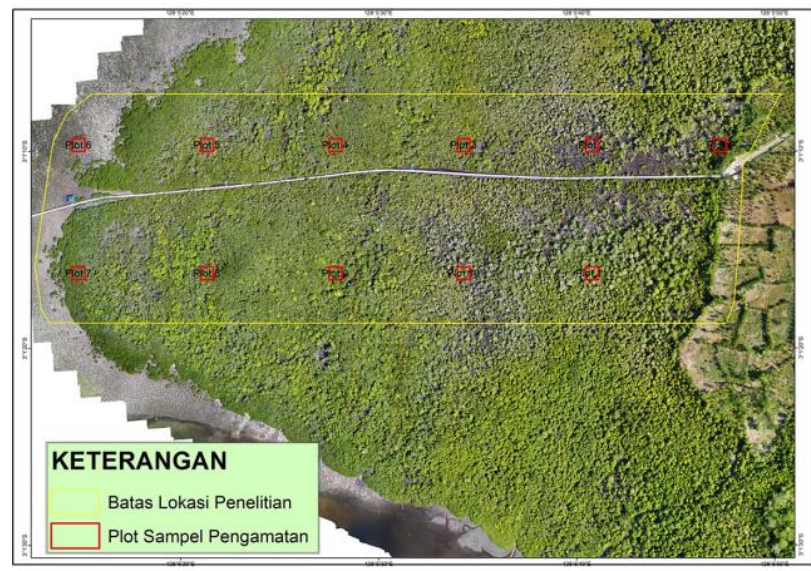

Gambar 2. Peta Plot Sampling Lapangan Indentifikasi Jenis Mangrove

\section{Uji Akurasi}

Uji ketelitian terhadap hasil interpretasi dilakukan dengan bantuan matriks uji ketelitian hasil pengembangan Short (1982). Salah satu langkah dalam menguji hasil segmentasi adalah menggunakan uji akurasi. Beberapa metode yang biasa digunakan dalam menguji hasil segmentasi diantaranya menggunakan indeks fragmentasi (Strasters dan Gerbrands 1991), area fit index (Lucieer 2004), serta penggunaan area, perimeter dan shape index (Neubert $d k k$. 2008). Namun pada penelitian ini, penentuan hasil segmentasi dan kombinasi parameter segmentasi terbaik dalam menentukan komposisi jenis vegetasi Mangrove adalah dengan cara menggunakan prinsip matrik konfusi (confusion matrix). Hasil segmentasi dibandingkan dengan data survei lapangan. Kelompok yang dibentuk untuk uji akurasi adalah data jenis dan data Estimasi Biomasa.

Untuk setiap hasil klasifikasi, kami menggunakan matriks kebingungan untuk memberikan metrik tertentu, termasuk Akurasi Pengguna (UA), akurasi produsen (PA), akurasi keseluruhan (OA). Matriks kebingungan adalah alat yang efektif untuk mengevaluasi kinerja 
klasifikasi.Ini memberikan deskripsi lengkap kesalahan untuk setiap kategori, termasuk kesalahan penyertaan dan kesalahan pengecualian dibuat oleh pengklasifikasi (Stehman, 1997). PA menunjukkan probabilitas suatu kategori tertentu diakui dengan benar. UA menunjukkan probabilitas bahwa sampel milik kategori tertentu, dan classifier dapat secara akurat mengurutkannya ke dalam kategori ini. Perbedaan utama antara PA dan UA adalah kardinalitas dari perhitungan akurasi (Zhao, 2003). Untuk PA, kardinalitas adalah jumlah total kategori oleh sampel referensi. Untuk UA, kardinalitas adalah jumlah total kategori menurut klasifikasi sampel. PA prihatin dengan kualitas metode yang digunakan untuk menghasilkan hasil klasifikasi, sementara UA berfokus pada kredibilitas masing-masing kategori dalam hasil klasifikasi. OA adalah rasio (\%) antara jumlah sampel yang diklasifikasikan dengan benar dan jumlah sampel pengujian (Abdel-Rahman, 2014). Contoh tabel Confusion matrix disajikan pada Tabel 2.

Tabel 2. Confusion Matrix ( Matriks kesalahan)

\begin{tabular}{|c|c|c|c|c|}
\hline & \multicolumn{3}{|c|}{ Data Lapangan } & Jumlah baris $\mathrm{n} 1+$ \\
\hline \multirow{3}{*}{ 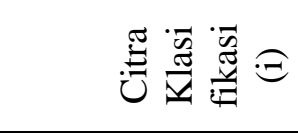 } & $\mathrm{n} 11$ & $\mathrm{n} 12$ & $\mathrm{n} 1 \mathrm{k}$ & $\mathrm{n} 1+$ \\
\hline & $\mathrm{n} 21$ & $\mathrm{n} 22$ & $\mathrm{n} 2 \mathrm{k}$ & $\mathrm{n} 2+$ \\
\hline & nk1 & $\mathrm{nk} 2$ & nkk & $\mathrm{Nk}+$ \\
\hline Jumlah Kolom n+j & $\mathrm{n}+1$ & $\mathrm{n}+2$ & $\mathrm{n}+\mathrm{k}$ & $\mathrm{n}$ \\
\hline
\end{tabular}

Di mana

$$
n i+=\sum_{j=1}^{k} \text { nij }
$$

Merupakan jumlah sampel hasil klasifikasi terhadap kelas $i$ dalam citra UAV hasil klasifikasi dan

$$
n+j=\sum_{i=1}^{k} \text { nij }
$$

Merupakan jumlah sampel yang diklasifikasikan tingkat akurasi baik itu OA, PA, UA, dapat kedalam kelas $j$ pada data lapangan.

dihitung dengan persamaan :

Persamaan yang digunakan untuk menghitung

$O A=\frac{\sum_{i=1}^{k} n i i}{n}$

$P A=\frac{n j j}{n+j}$

$U A=\frac{n i i}{n i+}$

$\mathrm{k}$ adalah jumlah baris pada matriks, $\mathrm{n}$ adalah jumlah pengamatan, D adalah jumlah pengamatan pada kolom ke-i dan baris ke-i dan

\section{HASIL DAN PEMBAHASAN}

D merupakan jumlah pengamatan pada kolom ke-j dan baris ke-j.

\section{Pengelolaan Citra Berbasis Objek}

Object Base Image Analisys (OBIA) atau dalam penelitian dikenal sebagai Analisis Citra UAV Bebasis Objek (ACUBO) merupakan 
metode klasifikasi yang dikembangkan dengan proses segmentasi dan analisis objek atau proses klasifikasi menggunakan citra UAV berdasarkan karakteristik spasial, spektral dan skala temporalnya, sehingga menghasilkan objek dari citra atau segmen-segmen yang selanjutnya digunakan untuk klasifikasi (Wang dkk. 2004; Blaschke 2010). Ide dasar dari proses ini adalah mengelompokan piksel-piksel yang berdampingan menjadi objek spektral yang sama melalui segmentasi, kemudian dilanjutkan proses klasifikasi pada objek sebagai unit proses terkecil (Schirokauer dkk, 2006 dalam Puturuhu, 2017). Dari hasil perekaman citra yang dilakukan diperoleh citra resolusi tinggi lokasi penelitianm, yang selanjunya untuk mendapatkan perbedaan jenis mangrove, dilakukan proses klasifikasi berbasis OBIA. Klasifikasi ini dilakukan dengan menggunakan aplikasi e cognition 96, melalui proses tree seperti pada gambar 3 .

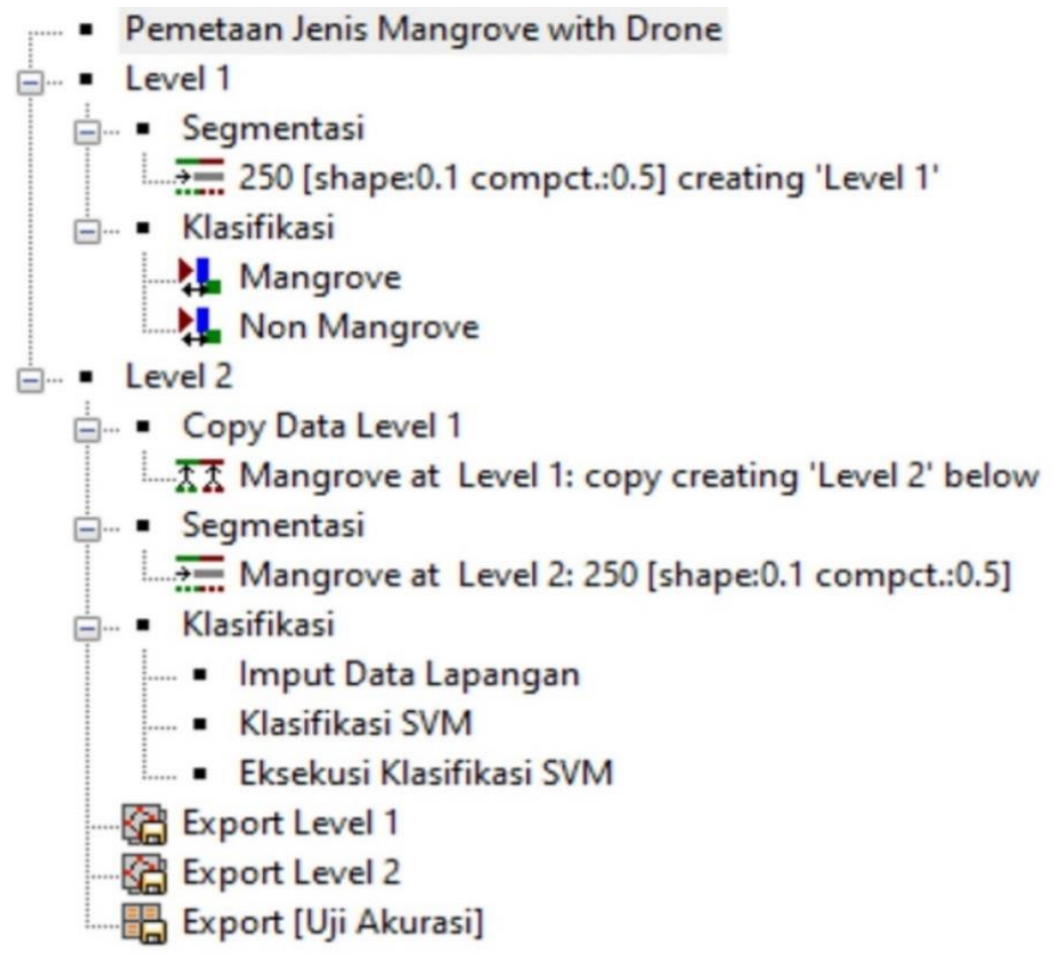

Gambar 3. Pohon Proses (Proces tree) OBIA

\section{Segmentasi}

Segmentasi citra adalah tahap permulaan dalam klasifikasi citra berorientasi objek, yang bertujuan untuk menemukan kesesuaian optimal diantara objek citra dalam fitur geografis yang ada pada objek dunia nyata (Qian dkk, 2007 dalam Puturuhu, 2017). Menurut Anggoro dkk. 2017, proses segmentasi akan menghasilkan sekumpulan layer obyek citra dalam suatu jaringan hirarki. Proses segmentasi dalam penelitian ini menggunakan algoritma multiresolution segmentation (MRS).

Segmentasi dengan penerapan beberapa skala yang berbeda (multiskala) dapat menghasilkan objek dengan jumlah dan bentuk yang berbeda berdasarkan kompleksitas suatu objek. Pada proses segmentasi dengan algoritma MRS terdapat tiga perameter penting yaitu shape (bentuk), compactness (kekompakan) dan scale (skala/ukuran) (Mastu, 2018).

Algoritma yang digunakan dalam segmentasi objek adalah multiresolution segmentation. Algoritma ini dipilih karena dianggap paling menggambarkan kondisi sebenarnya. Multiresolution segmentation diperkenalkan oleh Baatz \& Schape (2000) dimana algoritma ini merupakan teknik penggabungan region yang mengelompokkan area yang memiliki kemiripan dan piksel 
bersebelahan kedalam objek. Pada penelitian ini algoritma segmentasi yang digunakan yaitu algoritma multiresolution segmentation (MRS). Pembentukan objek pada proses segmentasi dilakukan dengan 2 Level yaitu yaitu Level 1 dan Level 2 dengan membuat segmen untuk memisahkan antara magrove dan non magrove pada Level 1 dan pada Level 2 dengan melakukan klasifikasi menurut jenis Mangrove, Penelitian ini dilakukan dengan Skala 100, 150 dan 250 dengan Shape 0,1 dan Compactnes 0,5 . Jumlah objek yang didapat dari proses segmentasi yang dilakukan adalah sebanyak 9.231 objek. Hasil segmentasi disajikan pada Gambar 4.

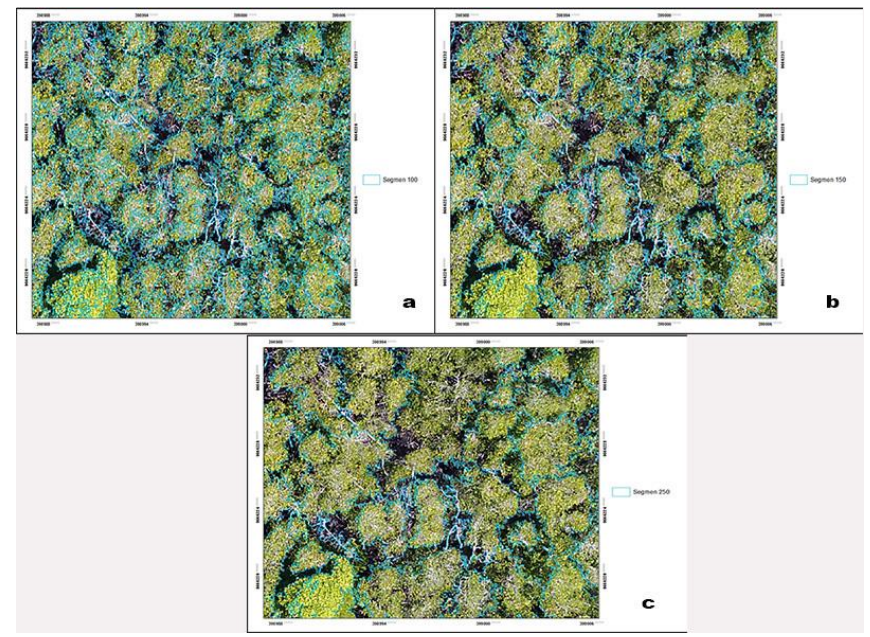

Gambar 4. (a) Skala 100, (b) Skala 150 dan (c) Skala 250

Penggunaan skala untuk proses segmentasi dalam OBIA ini sangat penting karena akan menentukan jumlah maksimum hetereogenitas dari objek gambar. Dari ketiga skala segmentasi yang di pakai dalam penelitian

\section{Klasifikasi Citra}

Klasifikasi dilakukan terhadap hasil segmentasi dengan dua Level yaitu Level 1

\section{Pemisahan Mangrove dan Non Mangrove}

Proses memisahkan mangrove dari fiturfitur lain, digunakan analisis citra UAV berbasis objek (ACUBO). ACUBO/OBIA adalah suatu proses yang dilakukan berdasarkan segmentasi, yang membagi gambar menjadi bermakna, berkelanjutan secara spasial dan secara spektral objek homogen atau kelompok piksel (Kamal, 2011). Dalam proses ACUBO yang menjadi tantangan utama adalah menentukan langkah- ini, maka hasil segmentasi dengan Skala 250 yang di pakai karena sesuai hasil pengamatan secara visul skala ini lebih efisien dan dapat mengcover tutupan tajuk mangrove dari yang kecil sampai dengan yang lebih luas.

dengan mengklasifikasikan Mangrove dan Non Mangrove sedangkan Level 2 dengan mengklasifikasi Jenis Mangrove.

langkah yang tepat untuk membedakan objek yang sama dari satu dengan yang lain.

Hasil segementasi yang dilakukan pada Level 1 penelitian ini kemudian dilakukan proses klasifikasi untuk memisahkan Mangrove dan Non Mangrove. Dari total objek yang di peroleh dari proses segmentasi sebanyak 31.904 objek. Diklasifikasi sebagai Mangrove jumlahnya sebanyak 28.937 objek yang ditunjukan dengan warna hijau sedangkan Non Mangrove jumlahnya sebanyak 9.231 objek yang 
ditunjukan dengan warna kecoklatan, seperti ditunjukkan pada Gambar 5

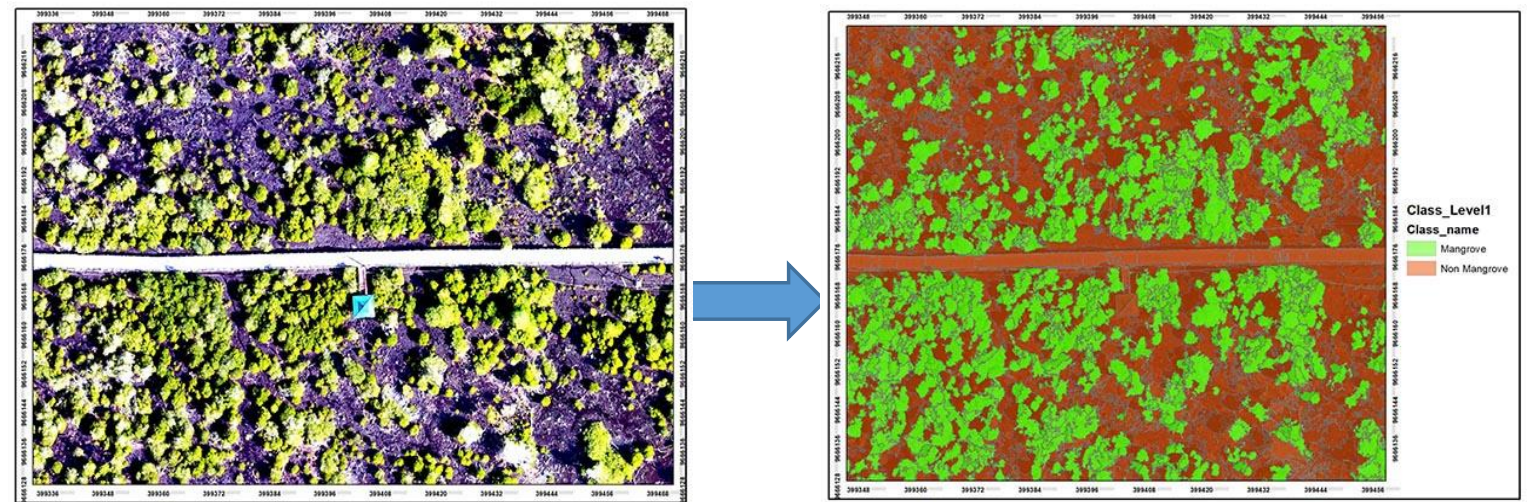

Gambar 5. Hasil Klasifikasi Mangrove dan Non Mangrove

\section{Klasifikasi Jenis Mangrove.}

Meningkatnya studi mangrove dan Implementasi pemetaan dengan menggunakan penginderaan jauh, tidak hanya dapat menyediakan informasi penting untuk pemantauan ekosistem, perubahan, dan luasnya hutan mangrove, tapi lebih dari itu dengan metode lanjutan, lebih memberikan hasil yang kontekstual dan probabilistik untuk meningkatkan akurasi klasifikasi, dan membedakan spesies individu.

Salah satu Metode klasifikasi paling populer adalah Support Vector Machines (SVM) yang didefinisikan oleh Vapnik, sebuah classifier berbasis margin besar dengan kapasitas generalisasi yang baik dalam uji coba dengan ukuran kecil yang dapat mengatur masalah dengan input dimensi tinggi (Vapnik 1998). SVM telah berhasil diterapkan dalam klasifikasi penginderaan jauh dengan data hiperspektral. Camps-Valls dan Bruzzone (2005) menunjukkan bahwa SVM memiliki kinerja yang sama atau lebih baik daripada pengklasifikasi lainnya dalam hal akurasi pada data hiperspektral.

Mangrove yang diekstraksi dari hasil penelitian, selanjutnya diklasifikasikan menggunakan algoritma SVM. Berdasarkan karakteristik yang dihasilkan dari segmentasi maka diperoleh 4 kelas atau jenias mangrove.. Empat jenis mangrove yaitu Ceriops tagal, Bruguiera gymnorisa, Rhizophora stylosa dan Rhizophora apiculata didukung juga oleh peneliti terdahulu dalam Tupan (2000). Untuk mewakili empat spesies mangrove utama yang ada di wilayah studi: Ceriops tagal, Bruguiera gymnorisa, Rhizophora stylosa dan Rhizophora apiculata (Gambar 4.15). Data lapangan yang ditemui di lapangan yang terbagai atas Ceriops tagal sebanyak 88 Pohon, Bruguiera gymnorisa sebanyak 41 Pohon, Rhizophora stylosa sebanyak 89 Pohon dan Rhizophora apiculata sebanyak 67 Pohon dengan presentase sebagaimana Gambar 6.

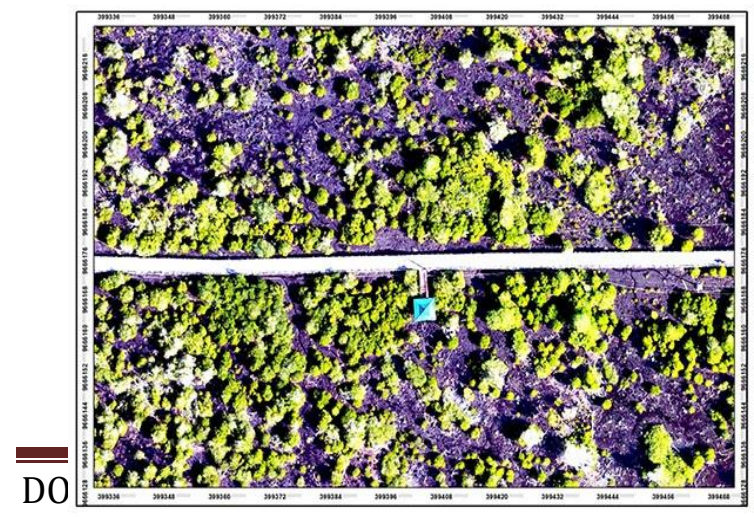

ISSN ONLINE: 2621-8798

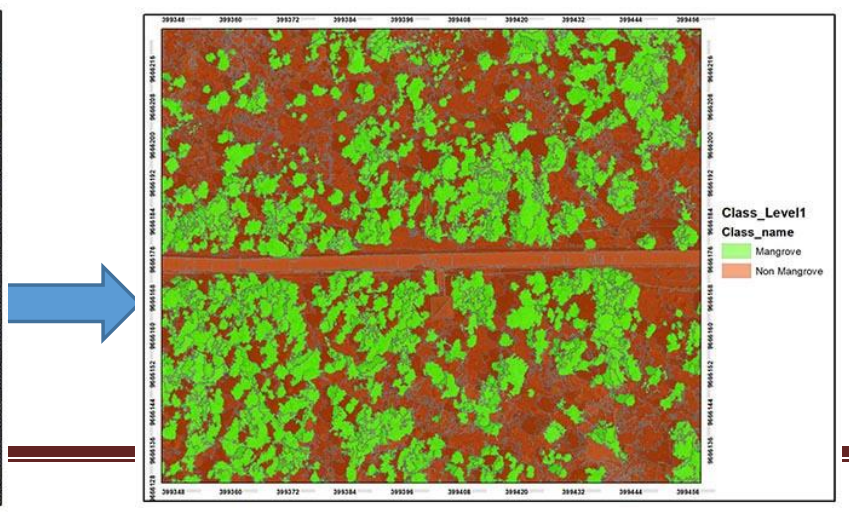

Page 141 

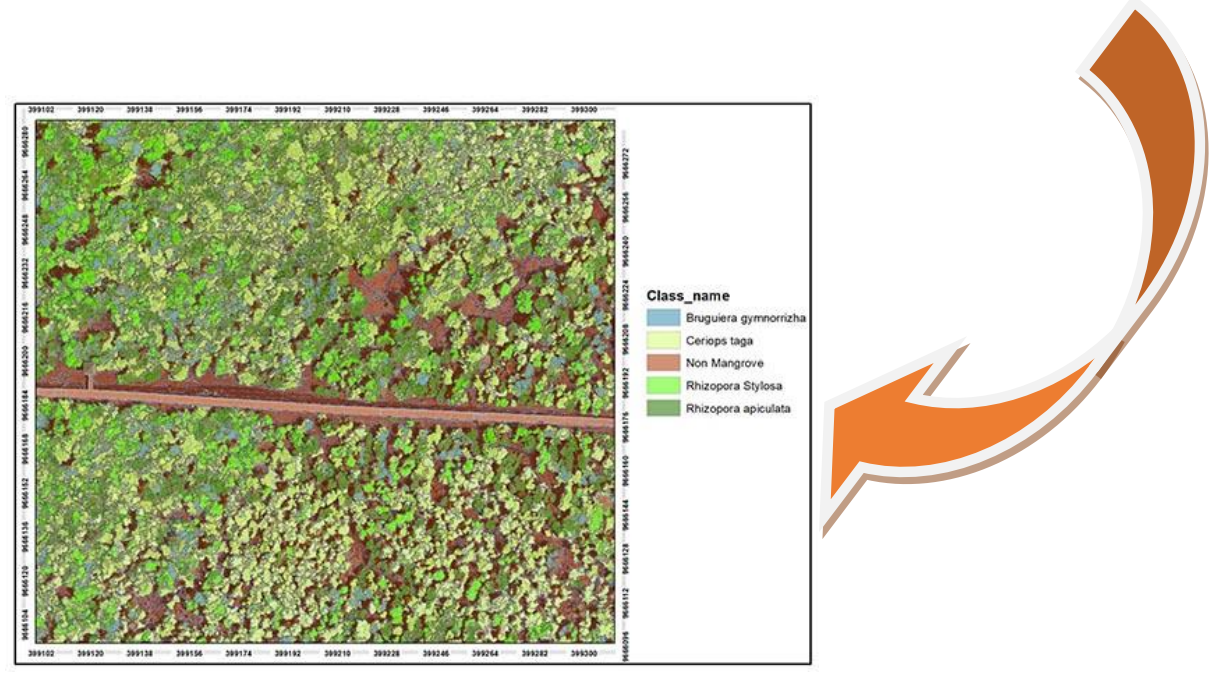

Gambar 6. Hasil Klasifikasi Jenis Mangrove

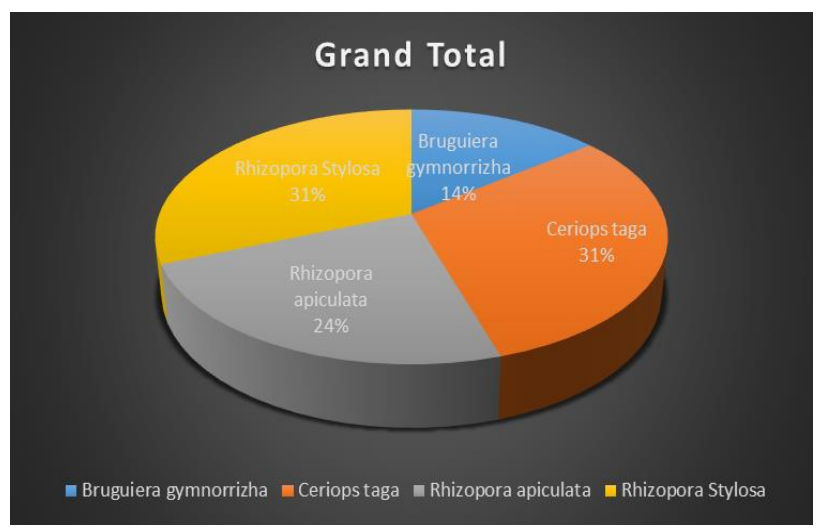

Gambar 7. Grafik Kasifikasi Jenis Mangrove

Rhizophora stylosa

Rhisopora stylosa Pada Plot 5 sebanyak

19 pohon, Plot 6 sebanyak 8 pohon, Plot 7
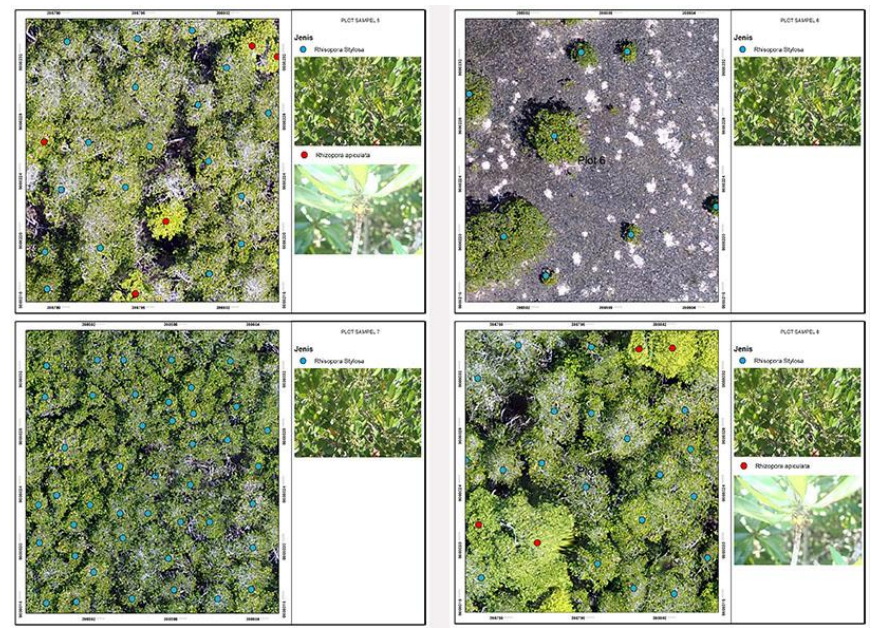

Gambar 8. Sebaran Jenis Rhisopora stylosa 
Bruguiera gymnorrizha

Bruguiera gymnorrizha pada lokasi penelitian ini di temui pada Plot 3 sebanyak 8 pohon, Plot 4 sebanyak 16 pohon dan Plot 9 sebanyak 17 pohon seperti pada Gambar 9.
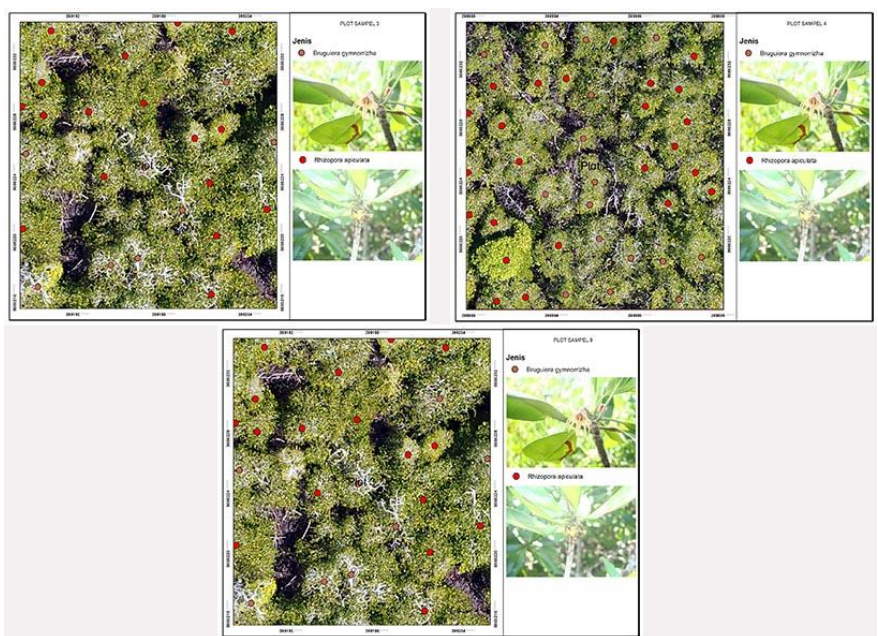

Gambar 9. Sebaran Bruguiera gymnorisa

Rhizophora apiculata

Rhizophora apiculata pada penelitian ini ditemui pada Plot 3 sebanyak 17 pohon, Plot
4 sebanyak 24 pohon, Plot 5 sebanyak 5 pohon, Plot 8 sebanyak 4 pohon dan Plot 9 sebanyak 17 pohon seperti pada Gambar 10
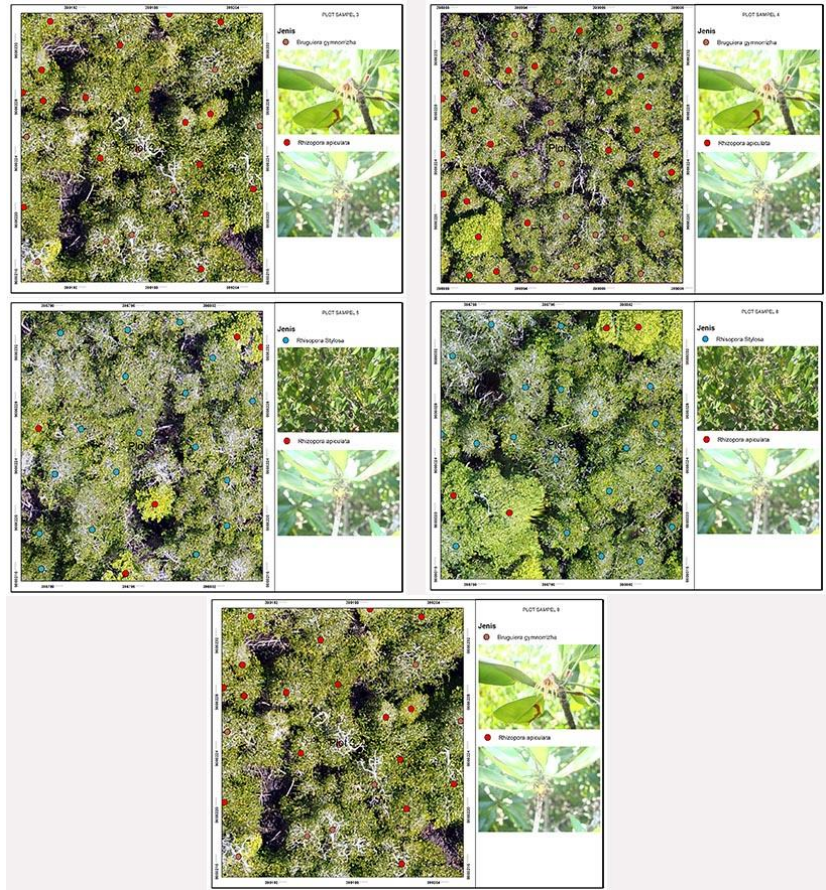


\section{Gambar 10. Sebaran Rhisopora apiculata}

\section{Ceriops tagal}

Pada penelitian ini Ceriops tagal dapat di temui pada Plot 1 sebanyak 13 pohon, Plot 2 sebanyak 29 anakan, Plot 10 sebanyak 24 pohon

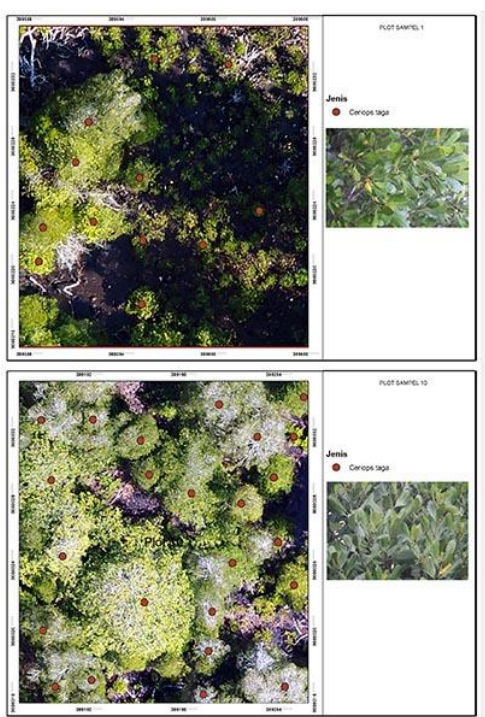

Gambar 11 Sebaran Ceriops tagal

Secara keseluruhan jumlah sampel yang diambil pada plot sampel dari keempat jenis mangrove disajikan pada Tabel 3, dan dan Plot 11 sebanyak 22 pohon seperti pada Gambar 11

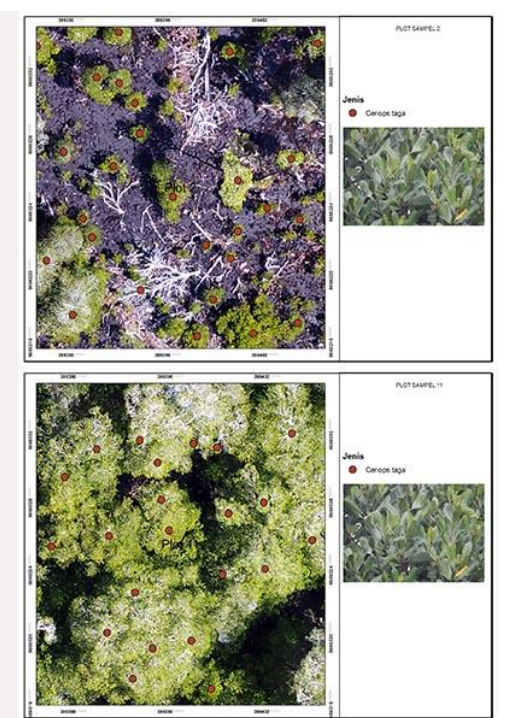

sebarannya secara visual Dari hasil perekaman

Drone dirunjukkan pada Gambar 12

Tabel 3. Hasil Pengambilan Sampel Lapangan

\begin{tabular}{|c|c|c|c|c|c|c|c|c|c|c|c|c|c|}
\hline \multirow{2}{*}{ No } & \multirow{2}{*}{ Jenis Mangrove } & \multicolumn{11}{|c|}{ Plot Sampel } & \multirow{2}{*}{$\begin{array}{l}\text { Grand } \\
\text { Total }\end{array}$} \\
\hline & & 1 & 2 & 3 & 4 & 5 & 6 & 7 & 8 & 9 & 10 & 11 & \\
\hline & Bruguiera & & & & & & & & & & & & \\
\hline 1 & gymnorrizha & & & 8 & 16 & & & & & 17 & & & 41 \\
\hline 2 & Ceriops taga & 13 & 29 & & & & & & & & 24 & 22 & 88 \\
\hline 3 & Rhizopora apiculata & & & 17 & 24 & 5 & & & 4 & 17 & & & 67 \\
\hline 4 & Rhizopora Stylosa & & & & & 19 & 8 & 43 & 19 & & & & 89 \\
\hline & Grand Total & 13 & 29 & 25 & 40 & 24 & 8 & 43 & 23 & 34 & 24 & 22 & 285 \\
\hline
\end{tabular}




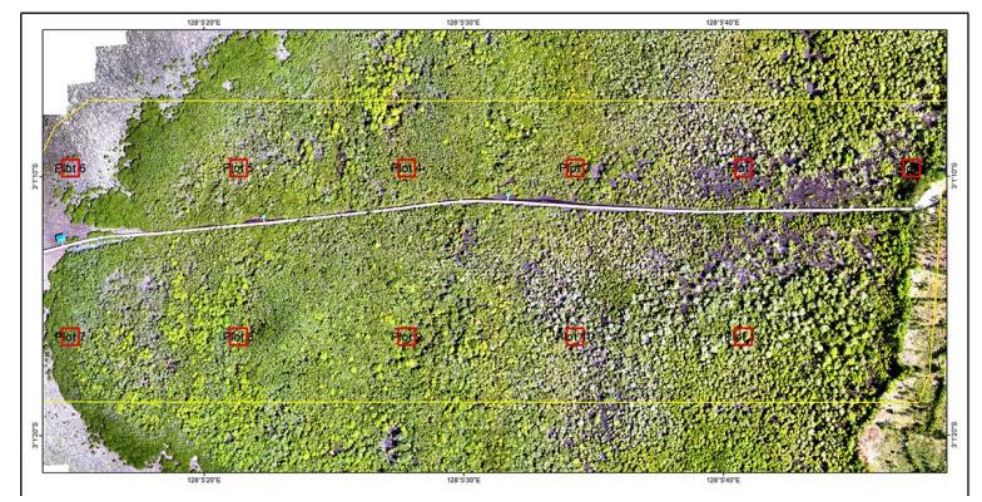

Gambar 12. Plot sebaran pengambilan sampel lapangan

\section{Uji Akurasi}

Keakuratan klasifikasi spesies mangrove dinilai pada tingkat piksel menggunakan teknik statistik deskriptif dan analitik. Dari 285 poin validasi acak dihasilkan di dalam sampel lapangan (plot $20 \mathrm{~m} \times 20 \mathrm{~m}$ ). Oleh karena itu, ada sejumlah besar poin validasi untuk penilaian akurasi setiap spesies. Menurut Congalton (2001), Peta yang dihasilkan diperiksa secara visual dan dibandingkan dengan pengamatan lapangan, gambar satelit dan foto udara.

Setelah dilakukan pengamatan lapangan maka dilakukanlah uji akurasi dibandingkan dengan hasil kalsifikasi dengan ACUBO. Hasil uji akurasi yang dilakukan dengan menggunakan Confussion Matriks terhadap data hasil penilitian, ditujukkan pada Tabel 4.

Tabel 4. Confusion Matriks hasil klasifikasi Mangrove

\begin{tabular}{lccccccc}
\hline \multicolumn{1}{r}{ Citra } & \multicolumn{9}{c}{ Sampel Lapangan } & \multirow{2}{*}{ Total } & \multirow{2}{*}{ UA } \\
\cline { 2 - 5 } \multicolumn{1}{c}{ Class } & BG & CT & RS & RA & NM & & \\
\hline BG & 32 & & & 4 & & 36 & 88,89 \\
CT & & 86 & 1 & 1 & & 88 & 97,73 \\
RS & & 1 & 86 & 1 & & 88 & 97,73 \\
RA & 9 & & 1 & 61 & & 71 & 85,92 \\
NM & & 1 & 1 & & & 2 & 0 \\
\hline Total & 41 & 88 & 89 & 67 & 0 & 285 & \\
\hline PA & 78,05 & 97,73 & 96,63 & 91,04 & 0 & OA & 92,98 \\
\hline
\end{tabular}

\section{Keterangan:}

$\mathrm{BG}=$ Bruguiera gymnorrizha

OA = Overal accuracy

$\mathrm{CT}=$ Ceriops taga

$\mathrm{UA}=$ User Accuracy

RS = Rhizopora stylosa

PA $=$ Producer Accuracy

RA = Rhizopora apiculata

$\mathrm{NM}=$ Non Mangrove

Hasil uji akurasi menggunakan Confusion Matriks menunjukkan Producer accuracy untuk BG adalah $78 \%$, CT adalah 97 $\%$, RS adalah 96,63\%, RA adalah 91,04\% sedangkan User Accuracy untuk BG adalah
$88,89 \%$, CT adalah $97,73 \%$, RS adalah $97,73 \%$ dan RA adalah $85 \%$ dengan demikian Overal Accuracy adalah 92,98\%. Menurut Campel 2002 dalam Puturuhu 2017 menyatakan bahwa nilai ambang akurasi keseluruhan sebesar $85 \%$ 
seringkali digunakan sebagai standar minimum bagi diterimanya suatu hasil pemetaan penutupan lahan/penggunaan lahan berbasis pengindaraan jauh.

Penggunaan algoritma SVM menunjukkan hasil akurasi yang tinggi, hal ini disebabkan karena SVM mampu mentransformasikan data pada input space ke ruang yang berdimensi lebih tinggi, dan optimisasi dilakukan pada ruang vector yang baru. Dari hasil ini menunjuklan bahwa SVM berbeda dari solusi algoritma machine learning pada umumnya, yang melakukan optimisasi parameter pada ruang hasil transformasi yang berdimensi lebih rendah daripada dimensi input space. Selain dapat meminimalkan faktor error pada training-set seperti yang banyak dilakukan algoritma machine learning lainnya, SVM juga dapat meminimalkan satu faktor lagi yang

\section{KESIMPULAN}

1. Proses ACUBO dalam penelitian ini dilakukan dengan memisahkan Data Ortomosaic menjadi segmen-segmen dengan alogaritma Multiresolution segmentation kemudian diklasifikasikan ke dalam tingkat spesies dengan algoritma Suport Vector Mechine (SVM) yang menghasilkan 4 (empat) Jenis Mangrove yaitu Rhisophora apiculata, Rhisophora stylosa, Burguire gymnorisa dan Ceriops tagal.

\section{DAFTAR PUSTAKA}

Ballari D, Orellana D, Acosta E, Espinoza A, Morocho V. 2016. UAV monitoring for enviromental management in galapagos island. The International Archives of the Photogrammetry, Remote Sensing and Spatial Information Sciences. XLI-B1:11052016.

Bendig J, Yu K, Aasen H, Bolten A, Bennertz S, Broscheit J, Gnyp ML, Bareth G. Combining UAV-based plant height from crop surface models, visible, and near infrared vegetation indices for biomass monitoring in barley. Int J Appl Earth Obs. 2015;39:79-87. dipengaruhi oleh dimensi VC (VapnikChervokinensis). Strategi ini disebut structural risk minimization (SRM), dan dalam SVM diwujudkan dengan memilih hyperplane dengan margin terbesar yang berfungsi sebagai pemisah dua buah kelas pada input space.

Menurut Mountrakis dkk. (2011) algoritma SVM dalam bidang penginderaan jauh memiliki kemampuan yang baik untuk menangani data dengan jumlah yang sedikit dan dapat menghasilkan akurasi yang lebih baik dibandingkan dengan teknik klasifikasi lainnya. Faktor utama yang mempengaruhi peningkatan akurasi dengan menggunakan algoritma SVM yaitu kemampuan membedakan objek dengan baik dari penggunaan data dengan ciri probabilitas empiris yang tidak diketahui (Zhang and Xie 2013).

2. Hasil uji akurasi dengan menggunakan Conffusion Matriks menunjukkan Producer accuracy untuk BG adalah $78 \%$, CT adalah $97 \%$, RS adalah 96,63 \%, RA adalah 91,04\% sedangkan User Accuracy untuk BG adalah $88,89 \%$, CT adalah 97,73 $\%$, RS adalah $97,73 \%$ dan RA adalah $85 \%$ dengan demikian Overal Accuracy adalah $92,98 \%$.

Benz UC, Hofmann P, Willhauck G, Lingenfelder I, Heynen M. 2004. Multiresolution, object oriented fuzzy analysis of remote sensing data for GIS-ready information. ISPRS Journal of Photogrammetry and Remote Sensing. 58:239-258.

Blaschke T. 2010. Object based image analysis for remote sensing. ISPRS Journal of Photogrammetry and Remote Sensing. 65(1):2-16.

Chang, A.J., Kim, Y.I., Lee, B.K., and Yu, K.Y. (2006), Estimation of individual tree and tree 
height using color aerial photograph and LiDAR data, Korean Journal of Remote Sensing, Vol. 22, No. 6, pp. 543-551.

Chang, A.J., Kim, Y.M., Kim, Y.I., Lee, B.K., and Eo, Y.D. (2012), Estimation of canopy cover in forest using KOMPSAT-2 satellite images, Journal of the Korean Society for Geospatial Information System, Vol. 20, No. 1, pp. 8391.

Chehata N, Orny C, Boukir S, Guyon D, Wigneron JP. 2014. Object-based change detection in wind storm-damaged forest using high resolution multispectral images. International Journal of Remote Sensing. 35(13):47584777.

Cheng, J.; Bo, Y.; Zhu, Y.; Ji, X. A novel method for assessing the segmentation quality of high-spatial resolution remote-sensing images. Int. J. Remote Sens. 2014, 35, 38163839 .

Chopping, M., Moisen, G., Su, L., Laliberte, A., Rango, A., Martonchik, J.V., and Petersm D.P. (2008), Large area mapping of south western forest crown cover, canopy height, and biomass using MISR, Remote Sensing of Environment, Vol. 112, No. 5, pp. 20512063.

Chuvieco E, Huete A. 2010. Fundamentals of satellite remote sensing. Boca Raton: Taylor $\&$ Francis. 468 p.

Conchedda G, Durieux L, Mayaux P. 2008. An object-based method for mapping and change analysis in mangrove ecosystem. International Journal of Remote Sensing. 63(5):578-589.

D’iorio, M.; Jupiter, S.D.; Cochran, S.A.; Potts, D.C. Optimizing remote sensing and GIS tools for mapping and managing the distribution of an invasive mangrove (Rhizophora mangle) on South Molokai, Hawaii. Mar. Geodesy 2007, 30, 125-144.

Everaerts J. 2008. The use of unmanned aerial vehicles (UAVs) for remote sensing and mapping. The International Archives of The Photogrammetry, Remote Sensing and Spatial Information Sciences. 38:1187-1192.
Getzin S, Nuske RS, Wiegand K. 2014. Using unmanned aerial vehicle (UAV) to quantify spatial gap patterns in forests. Remote Sens. 6(8):6988-7004.

Heenkenda, M.; Joyce, K.; Maier, S.; Bartolo, R. Mangrove species identification: Comparing worldview-2 with aerial photographs. Remote Sens. 2014, 6, 6064-6088. [CrossRef].

Held, A.; Ticehurst, C.; Lymburner, L.; Williams, N. High resolution mapping of tropical mangrove ecosystem susing hyperspectra land radar remotesensing. Int. J.RemoteSens. 2003,24,2739-2759.

Kamal, M.; Phinn, S. Hyperspectral data for mangrove species mapping: A comparison of pixel-based and object-based approach. Remote Sens. 2011, 3, 2222-2242.

Kattenborn, T., Sperlich, M., Bataua, K., and Koch, B. (2014). Automatic single palm tree detection in plantations using UAV-based photogrammetric point clouds, The International Archives of the Photogrammetry, Remote Sensing and Spatial Information Sciences, ISPRS, 5-7 September, Zurich, Switzerland, Vol. XL-3, pp. 139-144.

Mackenzie, J.R.; Duke, N.C.; Wood, A.L. The Shoreline Video Assessment Method (SVAM): Using dynamic hyperlapse image acquisition to evaluate shoreline mangrove forest structure, values, degradation and threats. Mar. Pollut. Bull. 2016, 109, 751763, doi:10.1016/j.marpolbul.2016.05.069.

Pham, T.; Yokoya, N.; Bui, D.; Yoshino, K.; Friess, D. Remote sensing approaches for monitoring mangrove species, structure, and biomass: Opportunities and challenges. Remote Sens. 2019, 11, 230

Zarco-Tejada, P.J., Diaz-Varela, R., Angileri, V., and Loudjani, P. (2014), Tree height quantification using very high resolution imagery acquired from an unmanned aerial vehicle (UAV) and automatic 3D photoreconstruction methods, European Journal of Agronomy, Vol. 55, pp. 89- 99. 